\title{
Pemanfaatan Batubara Kalori Rendah pada IGCC (Integrated Gasification Combined Cycle)
}

\author{
Muhammad Rizaldi Zaman', Sri Widodo Agung Suedy ${ }^{2}$ \\ ${ }^{1}$ Magister Energi, Sekolah Pascasarjana, Universitas Diponegoro; \\ ${ }^{2}$ Departemen Biologi, Fakultas Sains dan Matematika, Universitas Diponegoro;
}

Email : mrizaldizaman@students.undip.ac.id (M.R.Z), swasuedy@live.undip.ac.id (S.W.A.S);

\begin{abstract}
Abstrak : Kekhawatiran akan emisi gas rumah kaca dan krisis energi yang semakin dirasakan negaranegara didunia khususnya di Indonesia menyebabkan perlu dilakukan pengembangan energi alternatif yang bersih dan ramah lingkungan. Teknologi Integrated Gasification Combined Cycle dapat menjadi alternatif terbaik untuk mengatasi permasalaan tersebut. Penelitian ini dilakukan dengan tujuan untuk memberikan gambaran dan keuntungan dari proses IGCC berdasarkan penilitianpenelitian yang sudah ada sehingga dapat dilakukan pengembangan pemanfaatan IGCC menggunakan batubara lignit di Indonesia. Penelitian ini dilakukan dengan studi literatur, pengumpulan data dilakukan dari penelitian-penelitian yang sudah ada untuk mengetahui dampak dan metode yang digunakan untuk mengeringkan batubara rendah yang memiliki moisture tinggi. Analisis dalam penelitian dilakukan menggunakan perbandingan dari setiap literatur, sehingga diperoleh proses dan teknologi yang sesuai untuk pemanfaatan IGCC. Hasil penelitian menunjukkan pemanfaatan teknologi IGCC menggunakan batubara lignit sangat menjanjikan karena walaupun lignit memiliki keterbatasan dalam efisiensi termal karena moisture bahan bakar yang sangat tinggi namun hal ini bisa diminimalisir menggunakan proses drying. Jumlah batubara lignit yang melimpah di Indonesia dapat memudahkan pengembangan IGCC dan emisi yang dihasilkan lebih rendah daripada pembangkit fosil lainnya.
\end{abstract}

Kata Kunci : IGCC, lignit, emisi, batubara, pengeringan

\section{Pendahuluan}

Konsumsi listrik setiap negara selalu meningkat terlepas dari tahap perkembangan ekonomi setiap negara dan wilayah termasuk Indonesia. PDB per kapita Indonesia meningkat pesat di tahun 2000-an dan seterusnya. Pertumbuhan ekonomi Indonesia diperkirakan akan terus meningkat untuk konsumsi listrik mencapai 2,562 Terawatt jam (TWh) pada tahun 2050. Oleh karena itu, kapasitas pembangkit listrik perlu ditingkatkan sebesar 4,1 gigawatt (GW) per tahun, sebesar dimana $57 \%$ dari total kapasitas terpasang adalah PLTU (Badan Pengkajian dan Penerapan Teknologi, 2019).

Pembakaran bahan bakar menghasilkan emisi gas buang yang tinggi terutama gas $\mathrm{CO}_{2}$ yang meningkatkan konsentrasi polutan di udara. Batubara menyumbang $44 \%$ dari total global Emisi $\mathrm{CO}_{2}$ dan menjadi sumber GRK terbesar (gas rumah kaca) emisi seperti karbon dioksida $\left(\mathrm{CO}_{2}\right)$, metana 
$\left(\mathrm{CH}_{4}\right)$, dinitrogen oksida $\left(\mathrm{N}_{2} \mathrm{O}\right)$, ozon $\left(\mathrm{O}_{3}\right)$, dan klorofluorokarbon (CFC) (BP, 2020). Untuk mengurangi polutan tersebut sangat penting untuk meningkatkan efisiensi energi pada PLTU.

Mengurangi emisi gas $\mathrm{CO}_{2}$ dari sektor energi secara prinsip dapat dilakukan dengan beberapa cara, yaitu penggunaan teknologi hemat energi atau menggunakan Clean Coal Technology (CCT), substitusi bahan bakar dari karbon rendah (C) ke karbon yang lebih tinggi (C) atau bahan bakar dengan fraksi karbon yang lebih rendah, dan yang ketiga adalah $\mathrm{CO}_{2}$ atau penangkapan dan penyimpanan karbon (CCS) (Hashimoto et al., 2011). Clean Coal Technology (CCT) tidak menghilangkan emisi menjadi nol atau mendekati nol, meski begitu CCT dapat mengurangi emisi dari beberapa polutan dan limbah serta meningkatkan energi yang dihasilkan dari setiap ton batubara. Jadi, teknologi CCT untuk pembangkit listrik tenaga batubara sekarang lebih efisien dan ramah lingkungan. selain menggunakan CCT juga perlu ditambahkan carbon capture untuk meningkatkan efisiensinya. Tujuan dari carbon capture adalah mengumpulkannya dari berbagai sumber dan biasanya dicairkan untuk mengisi storage atau biasanya disuntikkan ke kedalam laut dan sumur minyak yang sudah tidak ada lagi digunakan (Gräbner et al., 2010; Wahid et al., 2020).

Penerapan CCT bermanfaat untuk mengembangkan sistem termal yang lebih efisien, yaitu untuk menghasilkan jumlah energi yang sama namun lebih sedikit input batubara dibutuhkan, sehingga memperluas ketersediaan sumber energi dan menghasilkan emisi yang jauh lebih rendah daripada teknologi konvensional. Berbagai CCT masih dalam pengembangan untuk menyediakan metode yang ramah lingkungan dalam penggunaan batubara, terutama untuk pembangkit listrik seperti USC4, IGCC, dan Gasifikasi Bahan Bakar Batubara Terintegrasi Siklus Gabungan Sel (IGFC). Di Cina penggunaan batu bara sebagai gasifikasi dianggap sebagai teknologi yang menjanjikan dan bisa menangani kebutuhan energi dan perubahan iklim (Wahid et al., 2020).

Pembangkit Integrated Gasification Combined Cycle (IGCC) sangat menonjol di bidang CCT, karena lingkungannya yang sangat baik serta efisiensi termalnya yang tinggi. Sistem IGCC menawarkan keunggulan antara lain fleksibilitas bahan bakar pasokan, produk sampingan komersial, yaitu slag gasifikasi dan unsur belerang dari unit desulfurisasi. Fitur-fitur itu bersama dengan kemampuan penggunaan batubara lignit sebagai bahan bakar umpan akan menjadi salah satu alternatif teknologi energi yang kompetitif (Gräbner et al., 2010).

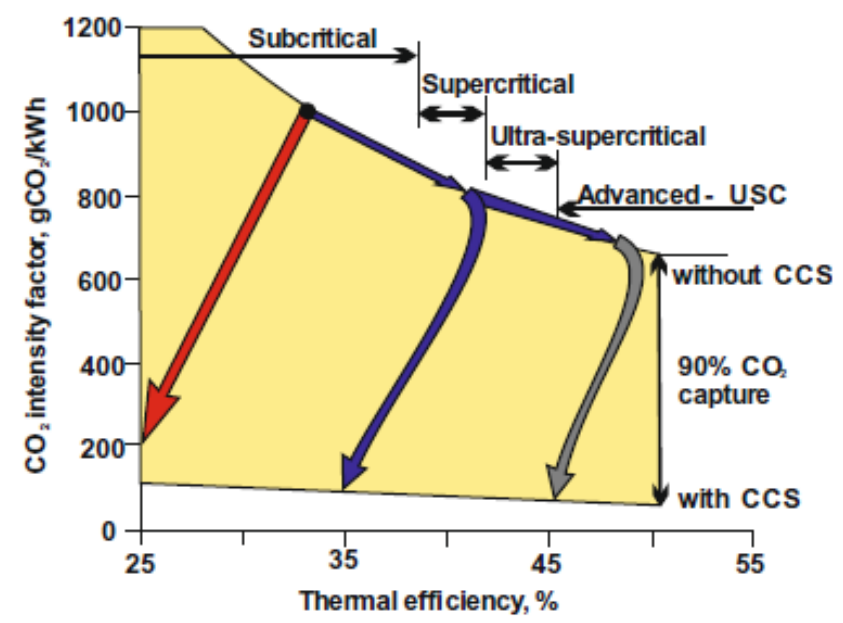

Gambar 1. Emisi CO2 dari berbagai pembangkit listrik (Atsonios et al., 2015) 
Vol. 1, No. 1, pp 35 - 44

doi: $10.14710 /$ jebt.2020.11156

Penggunaan IGCC untuk produksi listrik berbasis pada lignite tidak hanya memungkinkan pengurangan emisi $\mathrm{CO}_{2}$, tetapi juga memberi kesempatan untuk mengurangi polusi udara dan bahan bakar. Seperti yang terlihat pada Gambar. 1, pembangkit listrik berbahan bakar batubara subkritis berproduksi sekitar $900-1.000 \mathrm{~kg} \mathrm{CO} / \mathrm{MWh}$, tetapi dalam banyak kasus, nilai ini menjadi lebih besar karena kadar air bahan bakar tinggi atau operasi pada faktor beban rendah. Angka yang lebih kecil dapat dicapai, misalnya sekitar $740 \mathrm{~kg} \mathrm{CO} / \mathrm{MWh}$ untuk pembangkit listrik superkritis dan berpotensi $600 \mathrm{~kg} \mathrm{CO} / \mathrm{MWh}$ untuk teknologi batu bara terbaru. Penangkapan karbon dan penerapan sistem penyimpanan bisa menurunkan lebih lanjut emisi $\mathrm{CO}_{2}$, hingga $60-70 \mathrm{kgCO}_{2} / \mathrm{MWh}$ (Atsonios et al., 2015).

Pemanfaatan batu bara kalor rendah menjadi fenomena baru di Indonesia sejalan dengan program kelistrikan 35.000 MW yang sedang digenjot oleh pemerintah dengan keterlibataan kalangan swasta. Cadangan batubara kalori rendah masih sangat banyak (Tabel 1), karena batubara jenis ini tergolong non-ekspor,yang ternyata bila melalui proses gasifikasi akan memberikan nilai tambah yang signifikan dan ramah lingkungan. Peningkatan nilai tambah tersebut sesuai dengan amanat Undang undang No.04 tahun 2009 tentang Mineral dan Batubara, yaitu peningkatan nilai tambah melalui pengolahan dan pemurnian dalam negeri.

\section{Tabel 1.}

Sumber Daya dan Cadangan Batubara Indonesia

(Badan Pengkajian dan Penerapan Teknologi, 2019)

\begin{tabular}{|c|c|c|c|c|c|c|c|}
\hline \multirow{2}{*}{ Kualitas } & \multicolumn{4}{|c|}{ Sumber Daya (Juta Ton) } & \multicolumn{3}{|c|}{ Cadangan (Juta Ton) } \\
\hline & Tereka & Tertunjuk & Terukur & Total & Terkira & Terbukti & Total \\
\hline $\begin{array}{l}\text { Kalori Rendah } \\
(<5.100 \mathrm{kcal} / \mathrm{kg})\end{array}$ & $1,263.95$ & $5,913.98$ & $6,420.26$ & $3,598.19$ & $7,108.27$ & $7,121.47$ & $14,229.74$ \\
\hline $\begin{array}{c}\text { Kalori Sedang } \\
(5.100-6.100 \\
\text { kcal } / \mathrm{kg})\end{array}$ & $27,436.16$ & $19,822.35$ & $20,357.92$ & $67,616.43$ & $3,570.70$ & $6,841.66$ & $10,412.36$ \\
\hline $\begin{array}{c}\text { Kalori Tinggi } \\
(6.100-7.100 \\
\text { kcal } / \mathrm{kg})\end{array}$ & $3,967.88$ & $2,480.65$ & $2,804.63$ & $9,253.15$ & 541.60 & $2,769.20$ & $3,310.80$ \\
\hline $\begin{array}{c}\text { Kalori Sangat } \\
\text { Tinggi } \\
(>7.100 \mathrm{kcal} / \mathrm{kg})\end{array}$ & $1,726.74$ & 735.33 & 600.00 & $3,062.07$ & 264.19 & 240.21 & 504.40 \\
\hline Jumlah & $44,394.73$ & $38,952.31$ & $40,182.81$ & $123,529.84$ & $11,484.76$ & $16,972.54$ & $28,457.30$ \\
\hline
\end{tabular}

Pembagian kualitas batubara berdasarkan kelas nilai kalori tersebut sesuai dengan Keputusan Presiden Nomor 13 Tahun 2000 yang diperbarui dengan Peraturan Pemerintah Nomor 45 Tahun 2003 tentang Tarif Atas Jenis Penerimaan Negara Bukan Pajak yang berlaku pada Departemen Energi dan Sumber Daya Mineral. Angka calorific value yang sering dipakai oleh PLN dalam rangka desain PLTU adalah menggunakan standar GAR (gross as received). Perbedaan antara adb dan GAR dapat dihitung sesuai dengan nilai TM (total moisture) (Zhu, 2014). 
Vol. 1, No. 1, pp $35-44$

doi: $10.14710 /$ jebt.2020.11156

\section{Prinsip Kerja IGCC}

Integrated Gasification Combined Cycle (IGCC) adalah sistem tenaga termal generasi mendatang dengan efisiensi pembangkit listrik yang ditingkatkan secara signifikan dan kinerja lingkungan karena kombinasi dengan gasifikasi batu bara dan sistem Gas Turbine Combined Cycle (GTCC). Sistem IGCC tipe besar dapat meningkatkan efisiensi pembangkit listrik sekitar 15\% dan mengurangi CO2 dibandingkan dengan sistem tenaga panas berbahan bakar batu bara konvensional (Harkin et al., 2011).

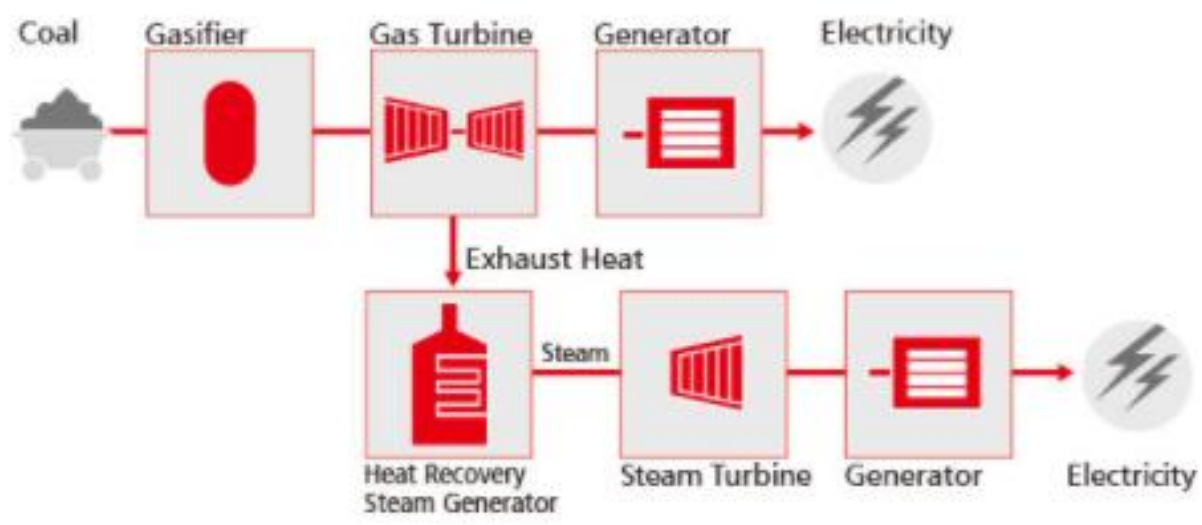

Gambar 2. Skema alir proses IGCC (Harkin et al., 2011)

Ada dua jenis teknologi IGCC yang sedang dikembangkan yaitu Air-Blown IGCC dan Oxygenblown IGCC.

1) Air Blown IGCC

Sistem Air blown IGCC (ABI) menggunakan udara untuk proses gasifikasi batubara. Pertama batubara diolah menjadi gas batubara di gasifier, dimana udara digunakan sebagai agen gasifikasi. Gas batubara menjalani proses desulfurisasi dan dedusting di unit pembersihan gas untuk memenuhi standar bahan bakar gas turbin dan gas buang. Gas bersih disuplai ke fasilitas siklus gabungan turbin gas (GTCC) (Gräbner et al., 2010).

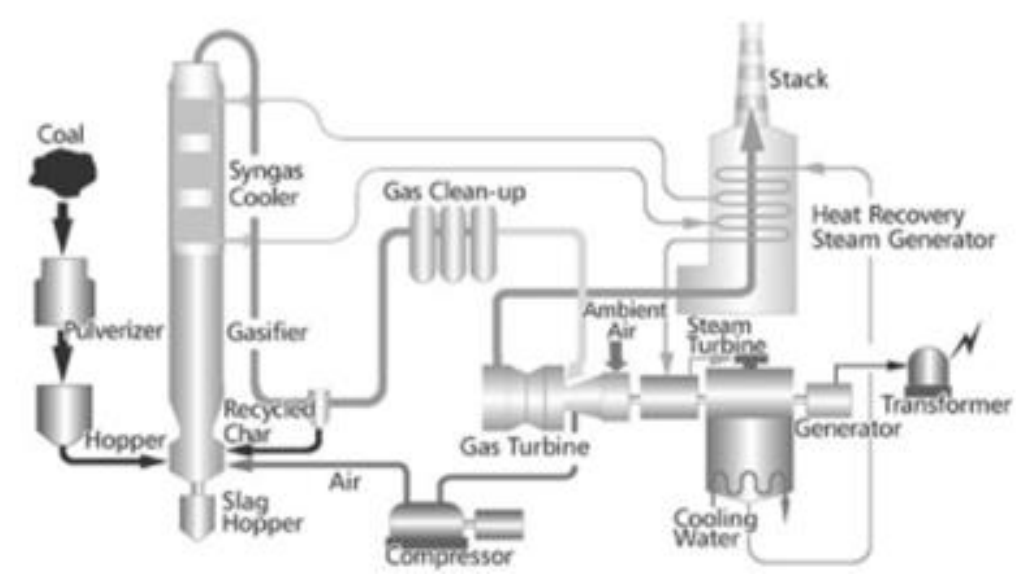

Gambar 3. Skema Air Blown IGCC (ABI) (Gräbner et al., 2010) 
Vol. 1, No. 1, pp $35-44$

doi: $10.14710 /$ jebt.2020.11156

Gas Turbine Combined Cycle (GTCC) membakar gas bersih sebagai bahan bakar untuk memutar gas turbin untuk pembangkit listrik. Panas dari gas buang dimanfaatkan lagi di Heat Recovery Steam Generator (HRSG) dengan menukar panas dengan air dan uap yang dihasilkan menggerakkan turbin uap untuk pembangkit listrik tambahan. Ditempatkan ke hilir dari gasifier, penukar panas mendinginkan gas batubara panas. Pada saat yang sama uap dihasilkan. Gasifier digabungkan ke dalam HRSG dan digunakan untuk pembangkit listrik dengan turbin uap. Modifikasi semakin meningkatkan efisiensi pembangkit listrik. ABI menyebabkan reaksi antara batubara yang disuplai dengan agen gasifikasi untuk menghasilkan gas mudah terbakar bersuhu tinggi yang utamanya terdiri dari karbon monoksida (CO) dan hidrogen $\left(\mathrm{H}_{2}\right)$ (Gambar 4). Gasifier memiliki struktur dua ruang dua tingkat, yang terdiri dari ruang bakar di tingkat bawah (pertama) dan reduktor di tingkat atas (kedua). Mengamankan jumlah kalori dari gas batu bara gasifikasi diperlukan untuk pengoperasian turbin gas, gasifier melelehkan abu dan membuangnya dengan lancar. Oleh karena itu, gasifier memainkan dua peran berbeda pada saat bersamaan (Harkin et al., 2011).

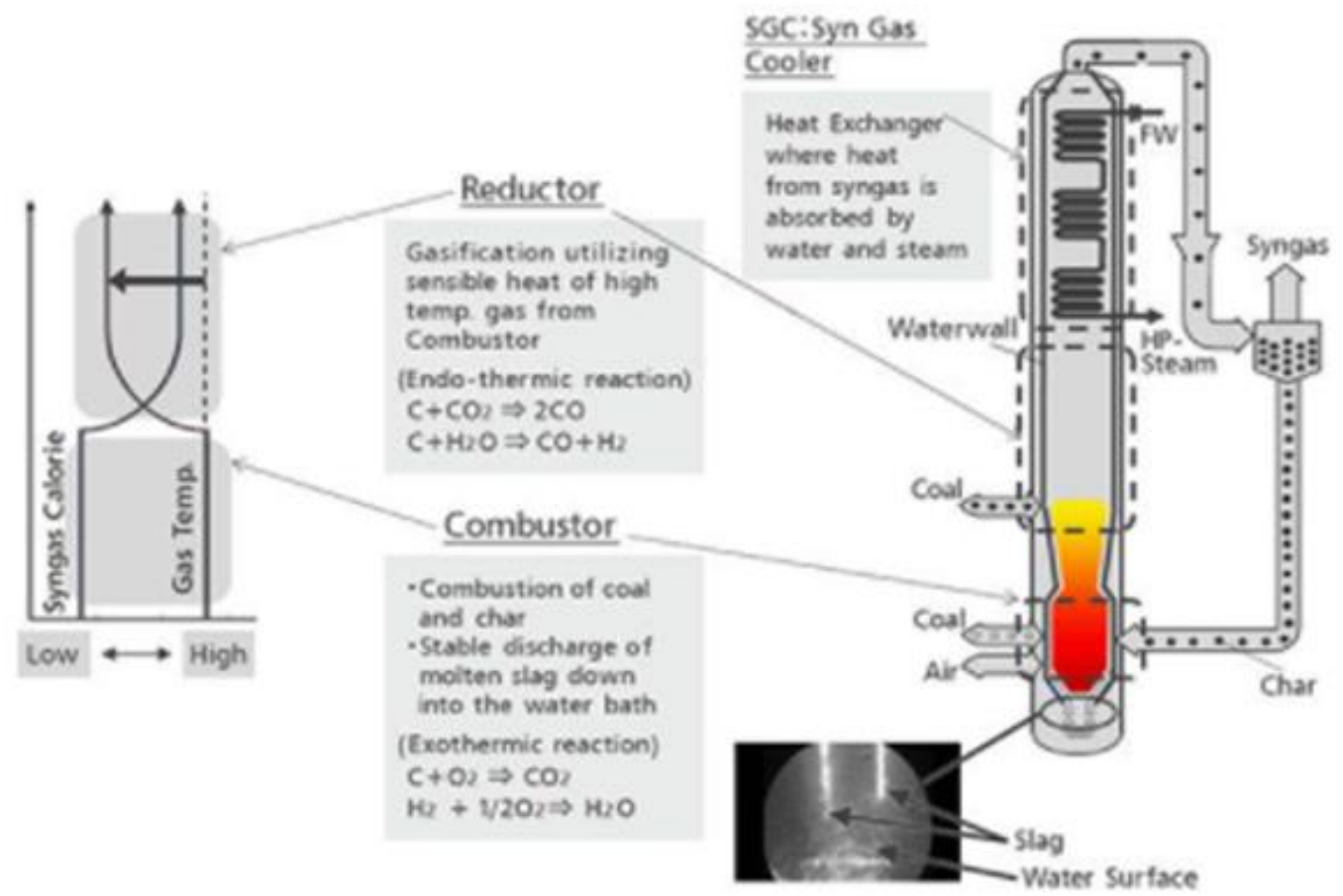

Gambar 4. Mekanisme dari Air Blown IGCC (ABI) (Gräbner et al., 2010)

2) Oxygen Blown IGCC (OBI)

Oxygen blown IGCC (OBI) didasarkan pada single-chamber, two-stage, swirl-flow entrainedbed yang dilengkapi dengan pembakar di tingkat atas dan bawah dari tungku silinder (Tanno \& Makino, 2018). Rasio oksigen / batubara yang sesuai dapat dialokasikan ke tahap atas dan bawah untuk menyesuaikan tahap yang lebih rendah dengan suhu yang diperlukan untuk abu leleh dan tahap atas dengan kondisi untuk reaksi gasifikasi yang efisien sesuai dengan jenis batubara yang digunakan. Selain itu, swirl flow dapat dihasilkan dalam gasifier untuk memungkinkan waktu tinggal partikel batubara dan menekan dispersi arang. 
Vol. 1, No. 1, pp $35-44$

doi: $10.14710 /$ jebt.2020.11156

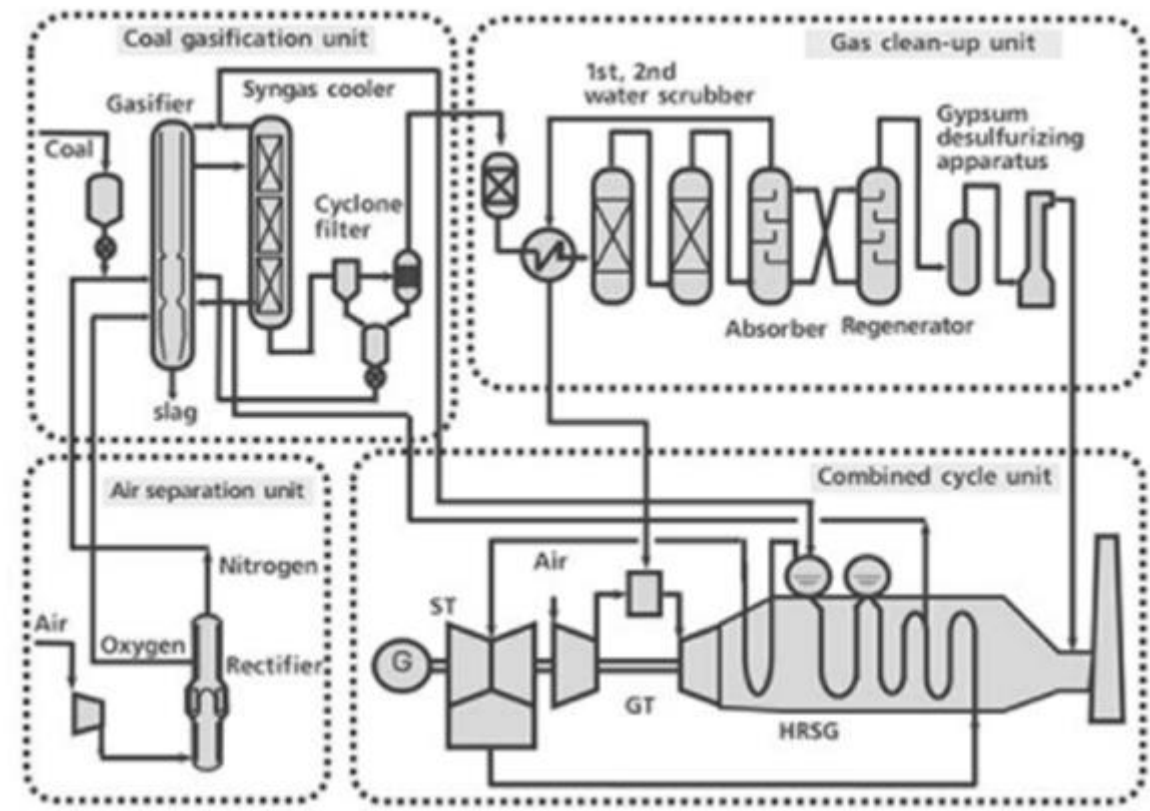

Gambar 5. Konfigurasi Oxygen blown IGCC (OBI) (Tanno \& Makino, 2018)

Langkah-langkah pada (OBI): 1) Rasio oksigen / batubara pada tahap atas dan bawah dioptimalkan, dan cara penyediaan gas segel diperbaiki pada saluran keluar gasifier (tenggorokan) untuk melindungi tenggorokan dari endapan abu (terak). 2) Pipa berpendingin air pada dinding gasifier dipersempit untuk meningkatkan pendinginan, dan material tahan panas disuntikkan dengan fusi ke bagian lokal bersuhu tinggi, untuk melindungi dinding gasifier. 3) Aliran gas bersuhu tinggi (aliran sirkulasi sendiri) dalam tungku dan nosel penggerak aliran-turun terak digunakan untuk mengisolasi dan memanaskan lubang keran abu cair (terak), untuk menyebabkan terak mengalir turun secara stabil. Langkah-langkah ini memecahkan masalah yang terkait dengan (OBI) (Gambar 6) (Harkin et al., 2011).

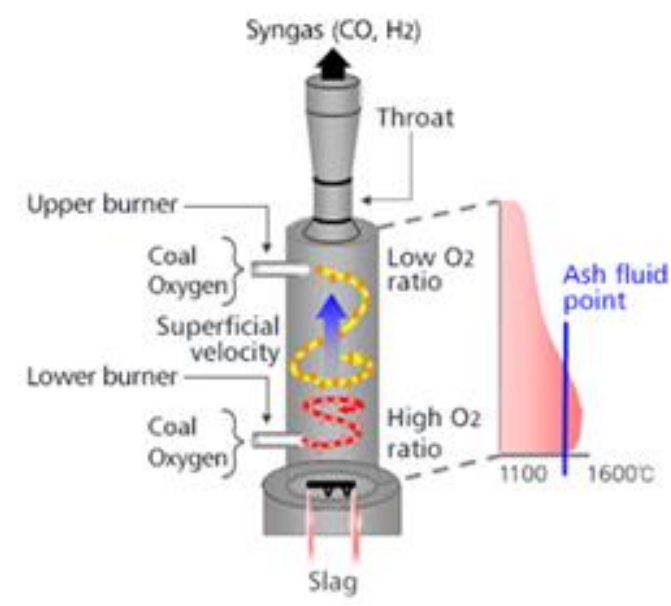

Gambar 6. Fitur Oxygen blown IGCC (OBI) (Tanno \& Makino, 2018) 
Vol. 1, No. 1, pp $35-44$

doi: $10.14710 /$ jebt.2020.11156

\section{Tinjauan Tentang Teknologi Pengeringan Lignit atau Brown Coal}

Pada pembangkit listrik berbahan bakar batubara konvensional, sulit untuk menggunakan batubara dengan suhu leleh abu rendah untuk mencegah slagging dan fouling. Di IGCC, gasifier melelehkan batubara dan membuang abu. Teknologi ini cocok untuk jenis batubara dengan suhu leleh abu rendah. Hal ini membuka jalan untuk menggunakan jenis batubara peringkat rendah dan petcoke yang secara konvensional sulit digunakan dalam pembangkit listrik (Gambar 7) (Tsakomakas et al., 2012).

Pembangkit listrik tenaga panas berbahan bakar lignit sebagian besar menggunakan beater mills. Selagi pembangkit ini mampu mengeringkan batubara kelembaban tinggi dengan menggunakan gas bersuhu tinggi dari tungku boiler; latent heat yang dihasilkan oleh penguapan moisture batubara hilang tanpa digunakan secara efektif ( $\mathrm{Xu}$ et al., 2020). Hal ini mengurangi efisiensi boiler, yang mengarah pada penurunan efisiensi pembangkit listrik. Demikian pula, dalam sistem IGCC, jika gas buang atau panas buangan dari turbin gas digunakan sebagai sumber panas untuk menghancurkan dan mengeringkan batubara sebelum memasukkannya ke dalam gasifier, kehilangan panas laten di gas buang selama penghancuran batu bara dan hilangnya limbah dalam peralatan desulfurisasi meningkat secara signifikan, yang menyebabkan penurunan hasil pembangkit. Oleh karena itu, kunci untuk meningkatkan efisiensi pembangkit listrik berbahan bakar lignit adalah dengan mengembangkan metode efektif untuk menggunakan panas laten yang dihasilkan dalam mengeringkan moisture dalam lignit.

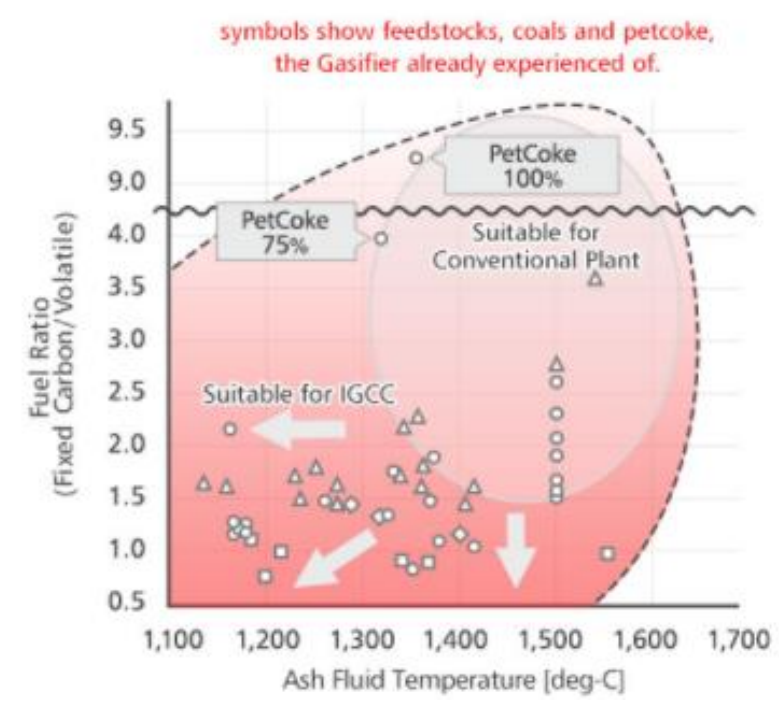

Gambar 7. Tipe Batubara yang dapat digunakan pada IGCC (Tsakomakas et al., 2012)

Gambar 8 adalah diagram alir sistem pengeringan batubara coklat yang dikembangkan oleh MHI. Lignit diumpankan dari bunker batu bara mentah, dihancurkan ke ukuran yang sesuai oleh penghancur, dan kemudian dipindahkan ke mesin pengering. Batubara uap kering kemudian didinginkan dan diumpankan ke fasilitas IGCC. Debu dibersihkan dari uap yang dihasilkan dari batubara. Beberapa uap ini dikompresi ulang oleh kompresor uap dan digunakan sebagai uap pemanas di pengering. Pendekatan ini memungkinkan pemulihan penguapan panas laten (Saw \& Pang, 2013). 
Vol. 1, No. 1, pp $35-44$

doi: $10.14710 /$ jebt.2020.11156

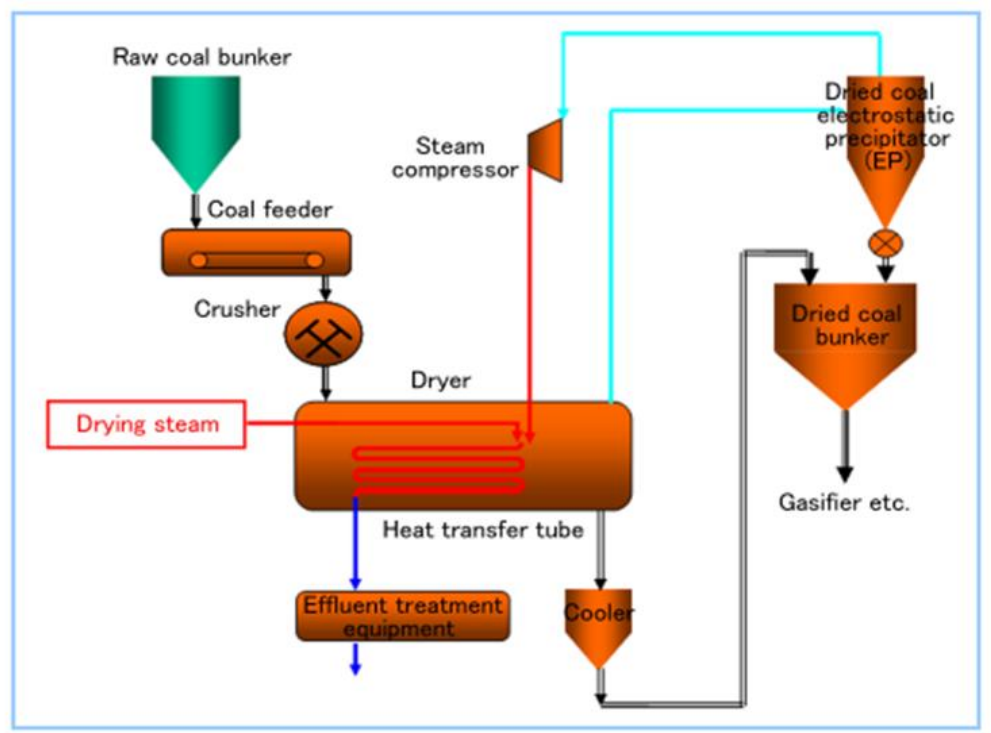

Gambar 8. Diagram alir pengeringan lignit (Tsakomakas et al., 2012)

Gambar 9 adalah diagram skema IGCC yang terintegrasi dengan pengeringan lignit peralatan yang dijelaskan di atas (Jaszczur et al., 2020). Dalam sistem ini, batubara coklat dikeringkan terlebih dahulu dengan uap di peralatan pengeringan. Batu bara gasifikasi dan pembersihan gas kemudian berlangsung dalam konfigurasi sistem yang persis sama seperti di unit IGCC berbahan bakar batubara bituminus, diikuti dengan pembangkit listrik menggunakan turbin gas dan uap. Oleh karena itu, sistem IGCC hembusan udara yang telah diuji dengan pabrik percontohan IGCC dapat digunakan apa adanya setelah pemanasan awal selesai. Meskipun memiliki kadar air yang tinggi antara $50-60 \%$ berat, batubara coklat lebih mudah digasifikasi daripada batubara bituminus karena memiliki rasio bahan bakar yang rendah (rasio karbon tetap terhadap zat yang mudah menguap) sebesar sekitar 1 . Selanjutnya lignit cocok untuk gasifikasi karena biasanya menunjukkan relatif titik leleh abu rendah (Oh et al., 2019).

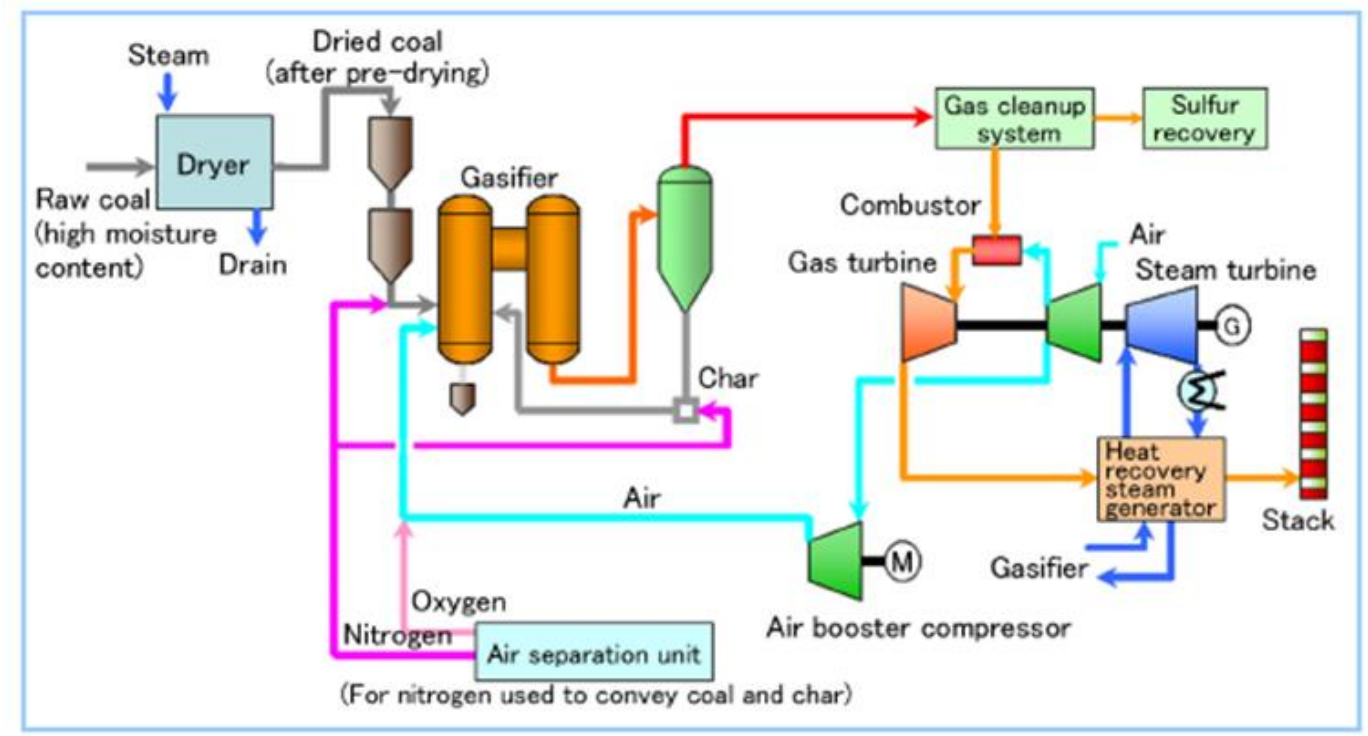

Gambar 9. Diagram Alir IGCC dengan Pengeringan Lignit (Atsonios et al., 2015) 
Vol. 1, No. 1, pp 35 - 44

doi: $10.14710 /$ jebt.2020.11156

\section{Efisiensi dan Hasil Pengurangan Emisi $\mathrm{CO}_{2}$ Menggunakan IGCC}

IGCC dapat meningkatkan efisiensi pembangkit dengan menerapkan teknologi efisiensi tinggi berdasarkan turbin gas berbahan bakar gas alam yang dipanaskan. Peralatan IGCC dengan (OBI) komersial yang didasarkan pada turbin gas memiliki efisiensi bersih sekitar $46 \%$ (HHV), sehingga menghemat emisi $\mathrm{CO}_{2}$ sekitar $10 \%$ dari PLTU USC. (OBI) menangkap $\mathrm{CO}_{2}$ dari gas yang memiliki kandungan $\mathrm{CO}_{2}$ tinggi sekitar $40 \%$ di bawah tekanan mulai dari 2,5 megapascal hingga 3,0 megapascal (penangkapan $\mathrm{CO}_{2}$ pra-operasi), sehingga aliran gas yang akan diolah lebih rendah daripada kandungan $\mathrm{CO}_{2}$ ditangkap (penangkapan $\mathrm{CO}_{2}$ pasca operasi) dari gas buang boiler. Hal ini memungkinkan untuk menggunakan unit pemulihan $\mathrm{CO}_{2}$ yang lebih kecil dan menekan penurunan efisiensi (Hashimoto et al., 2011).

Gambar 10 menunjukkan perkiraan efisiensi daya bersih dan laju emisi CO2 lignit pembangkit listrik tenaga batubara IGCC dalam skala yang sebanding dengan PLTU lignit. Dibandingkan PLTU lignit yang saat ini beroperasi, efisiensi pembangkit listrik IGCC secara dramatis lebih tinggi karena efisiensi turbin gas yang tinggi. Tambahan lagi, pabrik IGCC dapat mengeringkan lignit lebih efisien dengan memulihkan panas laten dan selanjutnya meningkatkan efisiensi pembangkit listrik sekaligus mengurangi laju emisi CO2. Selain itu, sistem IGCC mengeluarkan gas buang yang bersih dan dapat mengurangi volume abu dengan membentuknya menjadi terak (Xia et al., 2020). Mengganti pabrik yang ada ke sistem IGCC memiliki keuntungan besar hal keramahtamahan lingkungan dan efisiensi operasional.

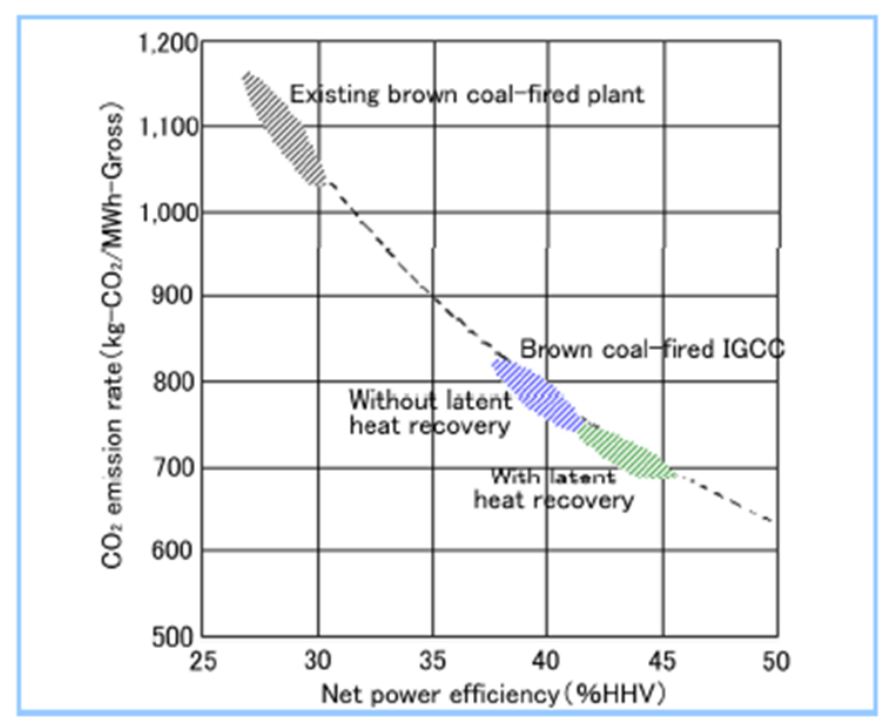

Gambar 10. Efisiensi dan Emisi $\mathrm{CO}_{2}$ dari IGCC Berbahan Bakar Lignit (Hashimoto et al., 2011)

\section{Kesimpulan}

IGCC sangat menjanjikan untuk sektor energi dan penggunaan lignit di masa depan dengan tambahan produksi syngas, memastikan rendahnya $\mathrm{CO}_{2}$ emisi ke udara atmosfer. Di banyak negara lignit (coklat batubara) memainkan peran utama dalam memenuhi kebutuhan daya. Di Indonesia, pangsa lignit dalam campuran energi melebihi 35\% produksi energi listrik total. Walaupun jenis ini memiliki keterbatasan dalam efisiensi termal karena moisture bahan bakar yang sangat tinggi namun hal ini bisa diminimalisir menggunakan proses drying. 


\section{Daftar Pustaka}

Atsonios, K., Violidakis, I., Agraniotis, M., Grammelis, P., Nikolopoulos, N., \& Kakaras, E. (2015). Thermodynamic analysis and comparison of retrofitting pre-drying concepts at existing lignite power plants. Applied Thermal Engineering, 74, 165-173. https://doi.org/10.1016/j.applthermaleng.2013.11.007

Badan Pengkajian dan Penerapan Teknologi. (2019). Indonesia Energy Outlook 2019: The Impact of Increased Utilization of New and Renewable Energy on the National Economy. Pusat Pengkajian Industri Proses dan Energi (PPIPE).

BP. (2020). Statistical Review of World Energy (70th ed.).

Gräbner, M., Morstein, O. von, Rappold, D., Günster, W., Beysel, G., \& Meyer, B. (2010). Constructability study on a German reference IGCC power plant with and without CO2-capture for hard coal and lignite. Energy Conversion and Management, 51(11), 2179-2187. https://doi.org/10.1016/j.enconman.2010.03.011

Harkin, T., Hoadley, A., \& Hooper, B. (2011). Optimisation of pre-combustion capture for IGCC with a focus on the water balance. Energy Procedia, 4, 1176-1183.

Hashimoto, T., Sakamoto, K., Yamaguchi, Y., Oura, K., Arima, K., \& Suzuki, T. (2011). Overview of Integrated Coal Gasification Combined-cycle Technology Using Low-rank Coal. Mitsubishi Heavy Insurtries Technical Review, 48(3), 19-23.

Jaszczur, M., Dudek, M., Rosen, M. A., \& Kolenda, Z. (2020). An analysis of integration of a power plant with a lignite superheated steam drying unit. Journal of Cleaner Production, 243, 118635. https://doi.org/10.1016/j.jclepro.2019.118635

Oh, H. T., Lee, W. S., Ju, Y., \& Lee, C. H. (2019). Performance evaluation and carbon assessment of IGCC power plant with coal quality. Energy, 188, 116063. https://doi.org/10.1016/j.energy.2019.116063

Saw, W. L., \& Pang, S. (2013). Co-gasification of blended lignite and wood pellets in a $100 \mathrm{~kW}$ dual fluidised bed steam gasifier: The influence of lignite ratio on producer gas composition and tar content. Fuel, 112, 117-124. https://doi.org/10.1016/j.fuel.2013.05.019

Tanno, K., \& Makino, H. (2018). Development tendency and prospect of high performance coal utilization power generation system for low carbon society. KONA Powder and Particle Journal, 2018(35), 139-149. https://doi.org/10.14356/kona.2018021

Tsakomakas, N. G., Pilavachi, P. A., \& Polyzakis, A. L. (2012). An economic comparison assessment of lignite and biomass IGCC power plants. Applied Thermal Engineering, 38, 26-30.

Wahid, A., Mustafida, D. R., \& Husnil, Y. A. (2020). Exergy analysis of coal-fired power plants in ultra supercritical technology versus integrated gasification combined cycle. Evergreen, 7(1), 32-42. https://doi.org/10.5109/2740939

Xia, C., Ye, B., Jiang, J., \& Shu, Y. (2020). Prospect of near-zero-emission IGCC power plants to decarbonize coal-fired power generation in China: Implications from the GreenGen project. Journal of Cleaner Production, 271, 122615. https://doi.org/10.1016/j.jclepro.2020.122615

Xu, J., Wang, T., Gao, M., Peng, T., Zhang, S., \& Tan, J. (2020). Energy and exergy cooptimization of IGCC with lower emissions based on fuzzy supervisory predictive control. Energy Reports, 6, 272-285. https://doi.org/10.1016/j.egyr.2020.01.003

Zhu, Q. (2014). Coal Sampling and Analysis Standards. IEA Clean Coal Centre Park House. https://www.usea.org/sites/default/files/042014_Coal sampling and analysis standards_ccc235.pdf 